\title{
Realizing the Existence of Multiple Forms of Knowledge: A Strategy Towards Seeing Education for Rural Transformation
}

\author{
Mahesh Nath Parajuli* \\ School of Education, Kathmandu University, Lalitpur, Nepal
}

\begin{abstract}
Education in Nepal is very structured and focused towards enhancing cognitive knowledge of students. Though Nepali policy documents often emphasize education as a means for development and social transformation, this paper argues that Nepali education has not given any direct consideration to this aspect. Some attempts are of course made towards seeing education as a means for rural transformation but it is a surprising reality that despite success of those pioneer and model building efforts, they could not be placed in government policy and practice. Deriving from those and other research and field experiences, the paper tries to explain this reality. Further, based on such Nepali experience, the paper argues on the need for identifying local practices of knowing and educating as accepted modes of knowing and educating. Such recognition would contribute to see the knowing beyond the formal and non-formal schooling process. This would help us realize that forms of knowledge are not one but multiple. In today's globalized context, it is of course important that people have knowledge that could link them with the world beyond their everyday living. At the same time, it is also equally important that we value their knowing and educating practices and recognize all forms of knowledge as important and end the binary and derogatory practice of labeling people as illiterate as we have given to the large mass of people.
\end{abstract}

Keywords: Rural transformation, local knowledge, knowing and educating, education, Nepal

\section{Introduction}

Nepal has consistently been giving high emphasis to education as a means for development. Beginning from 1956 the country has implemented 12 periodic plans (some were five years and some were three years) and is now moving on with the 13th. In almost all these plans the role of education in development was emphasized. However, in none of these plans, with the exception of a few cases, no efforts were made to build and implement programs and activities that would contribute towards strengthening a direct 
linkage between education and development. When I say direct linkage between education and development I mean direct contribution of education or educational institutions or activities to the local and national development process, to the extent that people could experience some meaningful and positive changes or transformations in their life quality in a sustainable manner as well as social transformations in a broader sense. Of course, education itself is one of the main components of development but here in this paper I intend to explore the relationship between education and development as being practiced in Nepal.

One of the objectives of this paper is to try to explain the gap between stated policy objectives and the actual practice regarding the relationship between education and development. Drawing from Nepali experience of weak direct relations between education and development, I argue for seeing knowing and educating as important local and internal processes. That is, we need to realize that the forms of knowledge are multiple and that people have their own practices of knowing and educating. Having such realization is accepting that labeling people as illiterate simply because they do not have standardized literacy and numeracy is not only unnecessary but also derogatory. Before going to these issues, I begin with a brief history of the modern education system in Nepal.

\section{Modern Education in Nepal}

Nepal is a country of immense socio-cultural and physical diversity. In this small country of about 26.5 million people spread over 147 thousand square kilometers there are a hundred plus castes or social groups speaking as many languages and practicing numerous cultures and patterns of life. A country of low per capita income (US\$ 706) Nepal is experiencing a stagnated growth profile in recent years with just three to five per cent growth per annum (Ministry of Finance [MOF], 2013). About a quarter of the population is said to be below the defined poverty line (National Planning Commission [NPC], 2013) and inequity in socioeconomic and political processes is one of the major challenges the country has not yet been able to address.

Historically looking, mountainous topography of the country which posed difficulties in movement gave rise to different socio-cultural and economic life patterns of the people living in different areas. Because of difficulties in movement and communication, people developed a localized cultural and economic pattern which used to be subsistence but selfsustained as well and in harmony with nature. People had developed their own knowledge, skills, system and practices to mobilize and manage the natural resources available to them, to handle their everyday context and relations, and to perform their forms of expression. There was minimal state interference in all these processes except in areas of collecting taxes and maintaining law and order (Stiller \& Yadav, 1979). Though some sporadic development projects were carried out by the state, there were no planned interventions till 1951. 
Political change that took place in the country in 1951 changed the state policy and this led to the beginning of planned development interventions in the country. This was the same time when there began the practice of development assistance at the international level. It was thus possible for Nepal to get international support and begin its developmental activities. In 1956 the government launched its first education development plan as part of its first five year development plan. The plan was very much clear in its objective of development of a centralized education system in the country and this was done in the name of developing national integration (Pandey, K. C., \& Wood, 1956). One other objective of the plan was to link education with development. That is, education was regarded as a means for development. The first education plan stated, "The country is in a state of utter barbarism and ignorance" (Pandey et al., 1956, p. 74). According to the plan, this was mainly due to lack of education in the country and the plan was clear that without technology and scientific education there could be no development, at least not the same level of development as in other countries. The plan thus gave emphasis to national integration and development and linked these with education. However, given the political instability at that time many of the provisions of the plan for improving the education system could not be realized (Aryal, 1970). Nevertheless, due to substantially increased government investment in education and due to peoples' attractiveness towards schooling, many schools were established across the country (Wood, 1965, p. 10).

In 1960, Nepal experienced a major political shift. The then King dismissed the parliamentary democracy and introduced a one party political system known as Panchayat with an autocratic and controlling approaches in all political and social processes. Following such political regime, in 1971 the government introduced the National Education System Plan (NESP) with radical reformulation of the education system in the country. Under NESP all education institutions in the country were nationalized and were brought under one centralized management. Accordingly, one management, one set of curriculum and textbooks, and one practice were introduced for the whole country. Similar to the first education plan of 1956, NESP also gave emphasis on linking education with development and national integration but within the value of the then political system. NESP was clear in its objective "to produce citizens who will conduct themselves in accordance with the Panchayat system" (Ministry of Education [MOE], 1971, p. 10). Linking education with development was also one of the objectives of the plan. It even adopted the slogan of "education for development" (MOE, 1971).

Nepal again experienced two major political shifts in 1990 and in 2006. In 1990, a popular movement overthrew the Panchayat system and the country returned to parliamentary and constitutional monarchy as its political system. However, this political system could not sustain long. Owing to the inefficiency of the political parties and their leaders and their corrupt practices and owing to age old practices of discrimination and exclusion and poverty, a communist party (Maoists) began an armed insurgency against 
the system. The Maoists were successful in exploiting peoples' dissatisfaction against the existing status quo and expanding and strengthening their armed and destructive insurgency throughout the country. The situation culminated in 2006 with a Comprehensive Peace Agreement between the government and the Maoists which eroded the age-old monarchy from Nepal, and then lead the country to become a republic.

These political events have greatly influenced educational processes in the country. With every political change the course of education has changed with it, but such changes have contributed little to improve aspects like quality, equity, relevance, efficiency, etc. and these have always been key challenges of Nepali education. Though the country has achieved impressive success in expanding access to primary schooling, quality of learning has always been questioned and grade repetition and dropout are persistent problems. Learning achievement studies have consistently shown that the average learning of students have only been less than or about $50 \%$ in key subject areas like Nepali, social studies, science, mathematics, etc. After this brief discussion of Nepali education and its context, I now move to analyze Nepali education policy and practice from the perspective of its contribution to development.

\section{Development in Nepali Education Policy and Practice}

When development practice in Nepal began in the 1950s, it was largely explained as moving away from the traditional life pattern that was more agrarian and rural to a life that would be modernized, mechanized and urbanized; apparent in the roads and buildings, mechanized and commercialized farms, schools and trainings, hospitals and factories, and so on. The first development plan implemented in 1956 wrote, "The central purpose of the program is to raise production, employment, standards of living and general well being throughout the country, thus opening out to the people opportunities for a richer and more satisfying life" (Government of Nepal [GON], 1956, p. 1). This was in line with the prevailing development ideology in the world that would call for directing development policies and practices in developing countries currently behind and moving to catch up with Western development. The argument was that with such strategy the developing countries would one day 'catch-up' with the developed countries and would then get rid of the status of the poor, underdeveloped, and backward. In this process, the traditional life pattern and knowledge base were rejected as not appropriate for growth and development and people were told to come out of 'darkness' (Pandey et al., 1956, p. 83). Development remained "part of a carefully cultivated mystification: it allows the developed to continue to indulge in a dangerous self-delusion while the underdeveloped interiorize the myth that they are indeed incapable, incompetent and the problem" (Carmen, 1996, p. 1).

The first education plan of the country implemented in 1956 noted, "There can be little improvement in our economic conditions without the help of technology and education" (p. 83). The document was clear in its message - the system, the knowledge base, and the 
practices developed through generations kept Nepalis 'utterly barbaric and ignorant' and if they want to come out of this 'darkness' they must discard their systems and practices and adopt modern technology and education that come from the West. This was precisely what Carmen (1996) referred to when stating 'a carefully cultivated mystification' inculcating into the minds of Nepalis that they were 'incapable, incompetent, and the problem'. This was how Nepal began its development endeavor and how the relationship between modern education or schooling and development was portrayed. Such idea was the result of the then prevailing development ideology that saw education as a means of development. The World Development Report of 1980 highly noted the role of education in overcoming poverty increasing incomes, improving health and nutrition, and in reducing the family size (World Bank, 1980). This sort of uncritical acceptance of role of education in development has however been questioned and it has been argued that such relationship is problematic (Chabbot \& Ramirez, 2006; Takala, 2010).

As discussed above, Nepali education plans of 1956 and 1971 placed high emphasis on linkage between education and development. This emphasis was there in all periodic development plans implemented in the country. The Chapter on education in the Tenth Plan (2002-07) began with the sentence "education is the vehicle for all-round development of the country" (NPC, 2003, p. 382). Likewise, the Twelfth Plan (2010-12) has described education as a means for economic and social transformation of the country (NPC, 2011, p. 177). Despite such emphasis on the relationship between education and development, no programs and activities are implemented in the education sector that would directly contribute to national and local development processes. Nepali education and development policy makers and planners saw the linkage between education and development only in an indirect sense. That is, the understanding is that when educational opportunities are increased and when women and men participate in the educational process and when they acquire some skills and knowledge through their schooling all these would obviously contribute to development. Thus, the linkage between education and development has been portrayed only in the theoretical sense. No efforts were made for a practical linkage between these two important social processes.

Nepali education policy is essentially focused on aspects like access, retention, quality, and outcome of the education system as well as on enhancing capacity development and management efficiency of the system. Likewise, inclusion and equity have also been key aspects of education intervention. Several interventions have been carried out in order to improve all these aspects mainly with donor support. Particularly, beginning from the 1980 s, several programs/projects have been implemented to improve education in the country, particularly at the school level. Some of these projects/programs focusing on primary or basic education were: in 1980s Education for Rural Development (popularly known as Seti Project), in 1990s Basic and Primary Education Project, and in 2000s 
Education for All 2004-09. The latest in this line is the multi-donor School Sector Reform Plan (SSRP) 2009-13 (MOE, 2009). Except for the Seti project, none of these projects/ programs had components that would help build a direct relationship between education and development in Nepal.

It is surprising to note that while periodic plans have consistently emphasized the relationship between education and development (though without any specific programs and activities toward this direction), education sector plans like BPEP, EFA 2004-09, and SSRP have ignored this aspect and have overtly focused on cognitive or instructional or learning related aspects. These plans have focused on several aspects, such as: increasing student enrollments; providing opportunities for learning to those who could not attend school through non-formal programs; preparing better teachers and curricula and textbooks; building better infrastructures and facilities; and improving quality and learning outcomes. Their focus was thus confined within the school or education system and hence they ignored to place education in the broader socio-cultural, political and economic context. This explains why schooling in Nepal is often blamed for their external characterization with little role and place in local and internal processes of the locality where they are located (see Bhatta, 2009; Shields \& Rappleye, 2008). Whenever I have the opportunity to go to different parts of the country and speak with individuals they agree on the importance of education in empowering people, but at the same time they also note that today's schooling has been contributing little to bringing about positive social changes in the locality, mainly because its programs have little to do with the local socio-cultural, economic and political realities.

As Nepali education policy so far has ignored to build a direct linkage between education and development, there would be no linkage found between education and rural development. One of the critical weaknesses of Nepali education policy is that it has been adopting a blanket approach without considering the reality that rural and urban areas possess different contexts and accordingly, different needs. Nepali education, thus, is very much centralized and structured as it has adopted the policy of one design, one curriculum, one set of textbooks, one management system, one practice of student assessment, and so on. In such a context, it makes little sense to claim that decentralization has been adopted in school governance.

It is not that Nepali education has completely ignored to build the relationship between education and development or specifically between education and rural development. Such practices have been carried out in Nepal even in government sector. Likewise, some NGOs have also focused their activities towards this direction. Unfortunately, they are just not up to the task. I now intend to discuss this aspect as examples of efforts made in Nepal to establish the direct linkage between education and rural development. 


\section{Nepali Practices of Linking Education and Rural Development}

Apart from the traditional home or community-based skills oriented teaching and learning, there were no organized practices of such education in Nepal before 1950. However, one such practice initiated by the government in 1947 was known as basic education. This program had the intention of providing some crafts based learning to students but the program could not survive long and collapsed within a few years of its initiation due to lack of commitment from the government itself (Sharma, 2003). One other failed program was efforts to vocationalize secondary education in 1971. Under this program all students in secondary education had to study some skills based courses. This effort could not last long because of systemic inefficiency and poor design.

Two important initiatives were carried out in mid-1970s with donor support in order to make education more relevant and meaningful to the rural areas and people (Shrestha, 1977). Both programs - one in Dandapakhar in Sindhupalchok district and the other in Lahachok in Kaski district - were mainly based on literacy initiatives and had attempted to link literacy with several other indicators of rural transformation, such as empowerment, gender relations, income generation, health and sanitation, etc. By linking learning with everyday realities of women and men participants, these initiatives had shown that if well designed and implemented, education could contribute to meaningful rural transformation.

In order to expand the experiences of these projects, particularly the Lahachok initiatives, the government implemented a new project Education for Rural Development, popularly known as the Seti Project, in the very remote and least developed far western parts of the country in the 1980s. This project could show how education could become a vehicle for rural development and transformation in remote rural areas if designed and implemented with a creative approach (UNESCO/UNDP, 1985). Focusing on both formal and non-formal modes of education, project activities were aligned to the needs of the people. Functional literacy, local content based reading materials, village reading centres, girls' education, teacher training, teacher/school resource centres, etc. were education focused inputs of the project. Different developmental activities like health and sanitation, agriculture, income generation, afforestation, etc. were also on focus. The project was considered very successful in achieving its objectives and bringing meaningful educational changes in the project areas.

The experience and success of the Seti project was however neither consolidated nor expanded in other parts of the country. This was mainly due to the characteristics of Nepali education which has remained highly compartmentalized and confined mainly within pedagogical and instructional processes which in turn were largely the outcome of donor intervention in education in Nepal. Inputs made in education were confined in schools and education centres. Despite the rhetoric of education for development given by periodic plans, the education sector projects/programs largely ignored the goals of education for 
development and were rarely seen in terms of programs, at least in the case of formal education sector. This reality illustrates that there are weaknesses in the linkage between periodic development plans and education sector plans. Except for a few experiments and projects, formal education in Nepal is largely detached from the needs of the local communities and with everyday life of people.

At least one innovation of the Seti project however was continued and expanded and that was the concept of Community Learning Centres (CLC). The CLC program began in Nepal in the 1990s with the objectives of making education more accessible to all and to promote development, empowerment and transformation (UNESCO, n.d.). CLCs focus mainly on the non-formal mode of learning and is "largely geared towards awakening people to define their own destiny" for a life with quality, freedom, and capability (UNESCO, 2011). Within 20 years of its history in Nepal, there are now about 1000 CLCs mainly in rural but also in urban areas in different parts of the country. The activities these centres have been carrying out vary, but many of them are mainly involved in running literacy classes for women and men and also for out-of-school children, skills training, income generation, and other activities. Likewise, these centres have also been supporting various interaction sessions among their own members as well as with other community members. These activities have greatly contributed to empowering people by improving their awareness, enhanced earning, improved life quality, and better communication skills. Further, these centres have also contributed to implementing developmental activities. It is true that not all centres are equally successful. Many are not able to perform any meaningful activities. However, it has now been established that CLCs hold great potentials in rural transformation (UNESCO, 2011).

It needs to be noted that aspects like equity and inclusion have been emphasized in educational policies and programs and several activities have been implemented for these purposes. There are policy measures and programs to enhance equity and inclusion of deprived and marginalized groups in education such as women, the poor and groups like Dalits and other castes, religion and language based social groups (MOE, 2009). All of these activities have greatly contributed to bringing about changes in Nepali society. Awareness and empowerment are two key words that characterize large parts of Nepali society these days. Those people who until some years ago were deprived and marginalized are now much aware of their rights and are also empowered in many ways (Central Bureau of Statistics [CBS], 2006; Aasland \& Haug, 2011). Several socio-cultural, economic and political processes are responsible for such changes but nevertheless the role of education has been important. Being literate or being able to read and write has contributed to bring positive changes in the life of many adults, more so in the case of women (UNDP, 2004). Being literate would mean enhancement of a woman's status and identity in her family and community as well as to boost her own morale (Robinson-Pant, 2000). Literacy in Nepal has also been linked with development discourse and has been seen as a contribution to 
development (Robinson-Pant, 2010). That is, some government supported programs and mainly I/NGOs run their literacy programs in association with other activities like group formation, income generation, savings and credits, awareness building, etc. Such an approach would directly link literacy or education with the development process.

Apart from these mainstream education activities, there are also some other educational activities that have been contributing towards rural transformation. Of particular importance are the practices of e-villages (Thapa, 2009), community radio, and mobilelearning. Under the idea of e-villages a cluster of villages are electronically linked and are provided services on different aspects including learning, health and sanitation, commerce, etc. After the late 1990s, FM stations and community radios proliferated in the Nepali landscape, presenting a powerful means for education, awareness and social and political transformation. Mobile learning is rather new for Nepal and only few attempts have been made to use this powerful device to educate people. As most part of the country is now under the mobile coverage and as the mobile users are rapidly expanding, even in remote rural areas, mobile learning could prove to be a powerful tool for education and rural transformation.

Street or open dramas and cultural programs are also popularly used in Nepal to educate people or to disseminate some specific messages. Several educational messages in agriculture, health, nutrition, sanitation, entrepreneurship, micro credit, income generation, skills, civic awareness, rights, group formation (e.g. mothers' group, child group, savings group, etc.), conservation and development of socio-cultural and natural heritage, etc. are being disseminated using these approaches. Several NGOs and other organizations are actively working in these different areas. Few sporadic efforts are also being made by NGOs and cooperatives where they take local schools as the centres for delivering some services like reading, learning, IT, health and nutrition, awareness and empowerment, income generation, entrepreneurship, etc. to the surrounding villages.

The discussion above shows the underlying tension regarding the design and direction of the education system in Nepal - whether to design education as a compartmentalized function or to design it as an integrated function. The first function would give a focused base to education whereas the second function would demand a broader base. The ongoing efforts of broad-based education, at present mainly confined to a small scale, have clearly shown the realization for the need to have a direct linkage between education and development. However, except for a few sporadic and small scale efforts for linking education and development, mainstream education policies and programs are highly compartmentalized and are limited within cognitive learning and development.

This reality could be explained by the historical roots of modern schooling in Nepal as well as its donor dependency. As I discussed above, schooling in Nepal had begun as an external project backed up by external ideology of modernization and development. This explains why schooling in Nepal always remained an exclusionary and centralized 
function controlled and run by people who are accountable to the government bureaucrats and not to the people of the community (Onta, 2000; Caddell, 2005; Shields \& Rappleye, 2008; Khanal, 2010). Schooling in Nepal was actually developed and implemented as a project designed to legitimize a particular culture of few - traditional and new elites that includes politicians, bureaucrats, businesspeople, and the civic leaders and to maintain their control. This practice was more direct and expressive before 1990 but is still there in one or other form (see Dixit, 2002). The same is true for the development practice carried out in the country. Planning in Nepal involved "state control of development by a centralized authority, it allowed the new ruling elites to monopolize all the resources, mostly from foreign countries" (Shrestha, 1997, p. 65). Schooling was only a tool of the state as political elites attempt to broaden and reinforce their own legitimate authority over civil society (Fuller, 1991, p. 13). The Nepali state or those who control it are thus utilizing education and development more so for fulfilling their own implicit objectives and less for bringing about social transformation in the country. Donors who have been playing a highly influential role in shaping the design of education in this country (Bhatta, 2011) have remained aligned with the elites and bureaucrats in these processes (Dixit, 2002).

Nepali education and schooling in particular have thus remained largely a hegemonic process which, as Gramsci sees, is the permeation of elitist values and norms as the values and norms of the whole society in the manner of supporting elites' power position (Burke, 1999/2005). By borrowing the Freirian concept, we can argue that present Nepali schooling largely follows a banking model where "knowledge is a gift bestowed by those who consider themselves knowledgeable upon those whom they consider to know nothing" (Frerie, 1970/2005, p. 72).

The above discussion makes it clear that the form of education and schooling as we have been practicing would contribute little to social transformation in the sense of forwarding positive and dynamic social changes that would enable individual and groups hitherto deprived to resist the traditional and modern hegemonies, and create a path of self-realization for a dignified livelihood and advancement. It should refer to positive social and political activities that help communities improve their livelihood and cope with the consequences of adverse changes as a result of globalization and other social and technological processes (Castles, 2001). Borrowing these same notions, we can conceptualize rural transformation as "a vision of pro-active and positive process of change and development of rural communities in the context of national and global changes" (UNESCO International Research and Training Centre for Rural Education [UNESCO INRULED], 2001). International Fund for Agricultural Development (IFAD) has conceptualized rural transformation as inclusive and sustainable development of rural areas in all its dimensions with poverty eradication at its core (IFAD, 2014). In order to achieve this goal of rural transformation there is a need for going beyond the formal and non-formal schooling practices and realizing that there are local practices of knowing and educating. 


\section{Realizing Local Practices of Knowing and Educating}

The history of educating and learning is as old as human civilization. However, modern universal and mass schooling is the development of the last 200-300 years and was developed in the West, in Europe, with the purpose of making citizens loyal to the state or state interests of religious, political, and economic purposes (Boli, Ramirez, \& Meyer, 1985). In order to achieve such an objective, schooling was developed as a standardized institution that functioned in an objective and rational manner that prepared students with these same values. When the concept of mass schooling gradually transferred to the nonWest countries, they carried the same logic and meaning. This happened because it was the West that exported the idea of development and schooling to the non-West world. When these ideas were being exported, by virtue of historical and political reasons, the nonWest world was only in the position of accepting what was given to it. While transferring the Western ideology of development and mass schooling, Western superiority or the Eurocentric concept made the non-Western values, norms and practices appear as irrational, illogical and superstitious and were thus rejected as 'utterly barbaric and ignorant'.

Here lies the contradiction and the problem. On the one hand, there is modern science using a standardized and objective approach for knowledge building that relies on speaking a fairly common language of generalization and abstraction, which operates at a macro level, and on the other, there are those people who derive their existence and sustenance through highly relational, experiential and unique approaches and work at micro level or at everyday context (Alessa, 2009). This fundamental difference between modern schooling - a representation of science - and traditional non-Western locales explains why non-West children cannot internalize the curricular topics and cannot make the learning they are expected to make. Besides, the whole approach of modern schooling has been hegemonic and has been working with the assumption that children and their parents and others in the community know nothing, and that schooling is there to give knowledge to people. Obviously, social or rural transformation cannot be realized with such an assumption and perspective.

Besides, as already discussed, modern schooling began by rejecting the traditional local practices of knowing and educating. In Nepal and elsewhere in the world people have developed particular ways of living and while doing so, they have also developed their own ways of knowing and educating to sustain and enhance those ways of living. One of the main epistemic values of such traditional ways of knowing and educating is its real life experience. In this system, "learning occurs through the process of observing and doing, and by interacting over long periods of time with knowledgeable elders and the natural environment" (Bates \& Nakashima, 2009, p. 6). That is, local knowledges are built over generations through a process of trial and error, and by the involvement of and for the benefits of all men and women and children living in the community, for current and future generations. Thus, the process of knowing and educating go hand in hand. While working 
and experiencing with their elders, children also contribute to knowledge building process. There is thus no beginning nor end - knowing and educating go on as a life time process.

Following the same process of knowing and educating, people in Nepal and elsewhere in the world have developed a complex practice of land management, built extensive systems of irrigation canals, maintained their fitness to be able to work, developed practice of trading, built patterns of relations and networks and leaderships, developed forms of expressions through different forms of art, and so on. While doing and achieving all these, many of them might still have remained unable to read and write and we, the educated people, have branded them as 'illiterate'. Governments around the world supported by donors and international agencies have been struggling hard to educate and liberate those people. We should end this sort of derogatory practice of seeing illiteracy as a shameful situation, a sin, and a waste of human potential and capacity (UNESCO, 2007). We have no right to devalue the dignity of all those people who cannot read and write but possess great knowledge and wisdom. This is injustice to them.

The need is thus to realize that modern education and schooling is not the only way of knowing and educating and that there are multiple forms of knowing and educating as being practiced by people and communities around the world. Individual or groups of people may not be able to read and write, but at the same time they might have many other life competencies. These must be recognized and valued. Moreover, instead of adopting the practice of binary categorization of labelling people as literate and illiterate we should see the knowledge and related practices on a continuum - realizing these is very much important while talking about social transformation.

It is not that we should deny modern science or modern schooling in today's globalized context. This knowledge is equally important for individuals and communities even for those living in their traditional locales. My argument is only on the need for realizing that forms of knowing and educating are multiple. By recognizing and honouring all those practices we would not only be enhancing our knowledge base but at the same time honouring all the cultures and the identity of men, women and children. This realization itself would be a step towards rural transformation. Moreover, borrowing Freirian concepts (Freire, 1970/2005), we can say transformation needs conscientization, dialogue and praxis. These are however completely absent in today's schooling and education. Hence, the need is changing today's schooling and its design so that it could promote experiential learning as per the everyday context and needs of the people.

\section{Conclusion}

Nepal began its modernized schooling as a means for development and social transformation. However, this remains underachieved due to the fact that Nepali schooling actually was not designed for this purpose. Hence, except for the indirect contribution towards aspects like empowerment and awareness, and few efforts of linking local schools 
as means for local development, schooling in Nepal has made little direct contribution towards rural development. This indicates that there is a contradiction between stated policy objectives and actual practices illustrating lack of linkage between periodic development plans and the education sector plan. These realities in turn show tension in the design of schooling - whether it should be confined to cognitive learning process or should also be contributing toward development and social transformation process. Due to this tension and its failure to contribute to the local development process, schooling in Nepal has remained an external project and thus it secures a limited role and place in the internal process in the local communities. Historical roots of Nepali schooling explain this reality. It was a project designed and implemented to legitimize the norms and values and practices of traditional and new elites. Its external origin and donor dependency have also contributed to escalating such tension and contradiction. Due to all of these reasons, schooling in Nepal has remained a hegemonic project following a banking model of pedagogic practice.

This Nepali experience has shown that today's schooling, at least till the foreseeable future, is not capable to contribute towards rural transformation. This was because modern schooling, a Western product, was designed to follow the principles of modern or Western science and thus was developed as a standardized project based on the norms of objectivity, rationality and generalization and abstraction. Modern schooling has also been characterized by rejection of local practices of knowing and educating despite the fact that communities around the world have developed extensive and complex systems of knowing and educating that are mainly relational, experiential, unique, and are internalized. Thus, in the discourse on education for rural transformation, it is important to see the ideological base as well as objectives and the design of the education system practiced in a country. In order to be able to contribute to rural transformation, an education system must be in accordance with the cultural norms and values practiced by the people in the area.

As local systems are important cultural resources for humans, it is important that these systems be recognized. That is, we need to realize that there are multiple forms of knowing and educating. Such realization in itself would be a step towards rural transformation as this would help make knowing and educating an experiential and dialogic process based on praxis. This also means not only taking the process of knowing and educating beyond formal and non-formal schooling, but also changing the design of schooling so that it could promote education that would be more relevant to the everyday context, needs and aspirations of the children. When we value people's knowledges and their system of knowing and educating this also implies that we end the disgracing practice of branding people as illiterate just because they are lacking reading, writing and numeracy skills. All these could be strategies towards rural transformation or specifically towards education for rural transformation. 
Realizing the Existence of Multiple Forms of Knowledge 115

\section{References}

Aasland, A., \& Haug, M. (2011). Perceptions of social change in Nepal: Are caste, ethnicity, and region of relevance? Journal of Asian and African Studies, 46(2), 184-201.

Alessa, L. N. (2009). The other way of knowing. Retrieved from http://schoolingtheworld. org/resources/essays/the-other-way-of-knowing/

Aryal, K. R. (1970). Education for the development of Nepal. Kathmandu, Nepal: Shanti Prakashan.

Bates, P., \& Nakashima, D. (2009). Introduction. In P. Bates, M. Chiba, S. Kube, \& D. Nakashima (Eds.), Learning and knowing in indigenous societies today (pp. 6-8). Paris, France: UNESCO.

Bhatta, P. (2009). Improving schools through decentralization: Observations from Nepal's primary education. In P. Bhatta (Ed.), Education in Nepal: Problems, reforms and social change (pp. 151-186). Kathmandu, Nepal: Martin Chautari.

Bhatta, P. (2011). Aid agency influence in national education policy-making: A case from Nepal's 'Education for All' movement. Globalisation, Societies and Education, 9(1), 1126.

Boli, J., Ramirez, F. O., \& Meyer, J. W. (1985). Explaining the origins and expansion of mass education. Comparative Education Review, 29(2), 145-170.

Burke, B. (1999/2005). Antonio Gramsci, schooling and education. Retrieved from http:// infed.org/mobi/antonio-gramsci-schooling-and-education/

Caddell, M. (2005). Listening to local voices? International targets and decentralized education planning in Nepal. International Journal of Educational Development, 25, 456-469.

Carmen, R. (1996). Autonomous development. Humanizing the landscape: An excursion into radical thinking and practice. New Delhi, India: Vistaar Publications.

Castles, S. (2001). Studying social transformations. International Political Science Review, 22(1), 13-32.

Central Bureau of Statistics. (2006). Resilience amidst conflict: An assessment of poverty in Nepal, 1995-96 and 2003-04. Kathmandu, Nepal: Author.

Chabbott, C., \& Ramirez. F.O. (2000). Development and education. In M. T. Hallinan (Ed.), Handbook of the sociology of education (pp. 163-188). Notre Dame, IN: Springer.

Dixit, S. (2002). Education, deception, state and society. In K. M. Dixit \& S. Ramchandran (Eds.), State of Nepal (pp. 193-211). Kathmandu, Nepal: Himal Books.

Freire, P. (1970/2005). Pedagogy of the oppressed (30th anniversary edition) (M. B. Ramos, Trans.). New York, NY: Continuum.

Fuller, B. (1991). Growing up modern: The Western state builds third-world schools. London, England: Routledge.

Government of Nepal. (1956). Draft five year plan: A synopsis. Kathmandu, Nepal: Author. International Fund for Agricultural Development. (2014). A rural transformation agenda. 
Retrieved from http://www.ifad.org/governance/post2015/Overview_Policy Brief_web. pdf

Khanal, P. (2010). School decentralization in Nepal: A disjuncture between macro level advocacy and micro-level reality. Education Research for Policy and Practice, 9(3), 145-158.

Ministry of Education. (1971). Rashtriya shikchhya paddhati: 2028-2032 sammako yojana [The national education system: Plan for 1971-1975]. Kathmandu, Nepal: Author.

Ministry of Education. (2009). School sector reform plan 2009-2015. Kathmandu, Nepal: Author.

Ministry of Finance. (2013). Economic survey 2012-13. Kathmandu: Author.

National Planning Commission. (2003). Dasaun yojana 2059-2064 [Tenth plan 2002-2007]. Kathmandu, Nepal: Author

National Planning Commission. (2011). Tri-barhsiya yojana 2067/68-2069/70 [Three year plan 2010/11-2012/13]. Kathmandu, Nepal: Author.

National Planning Commission. (2013). Terhaun yojana 2070/71-2072/73: Adhar patra [Thirteenth plan 2013/14-2015/16: Approach paper]. Kathmandu, Nepal: Author.

Onta, P. (2000). Nepal education: Finding a ray of hope. Retrieved from http://www.epw. org.in/35-47/comm6.htm\#top

Pandey, R. R., K. C., K. B., \& Wood, H. B. (Eds.). (1956). Nepalma shikchhya [Education in Nepal] (Report of the Nepal National Educational Planning Commission). Kathmandu, Nepal: Bureau of Publications, College of Education.

Robinson-Pant, A. (2000). Women and literacy: A Nepal perspective. International Journal of Educational Development, 20(4), 349-364

Robinson-Pant, A. (2010). Changing discourses: Literacy and development in Nepal. International Journal of Educational Development, 30(2), 136-144.

Sharma, G. (2003). Nepalko saichhik itihaas bhag 2 [The history of Nepali education system part II]. Kathmandu, Nepal: Makalu Books and Stationers.

Shields, R., \& Rappleye, J. (2008). Uneven terrain: Educational policy and equity in Nepal. Asia Pacific Journal of Education, 28(3), 265-276.

Shrestha, N. R. (1997). In the name of development: A reflection on Nepal. Kathmandu, Nepal: Educational Enterprise.

Shrestha, R. (1977). Adult literacy in Nepal: A report. Kathmandu, Nepal: Tribhuvan University. Retrieved from http://rameshshrestha.com/upload/research/Adult_Literacy_ in_Nepal_RS.pdf

Stiller, L. F., \& Yadav, R. P. (1979). Planning for people. Kathmandu, Nepal: Sahayogi Prakashan.

Takala, T. (2010). Contributions of formal education to social development: What do we know on the basis of research evidence? Journal of Education and Research, 2, 1-8. 
Thapa, D. (2009, May 12). ICT for rural development and the role of media. The Kathmandu Post, p. 8.

UNDP. (2004). Nepal human development report 2004: Empowerment and poverty reduction. Kathmandu, Nepal: Author.

UNESCO. (2007). EFA global monitoring report 2008: Education for all by 2015. Will we make it? Paris, France: Author.

UNESCO. (2011). Final report on assessing the community learning centers in Nepal to achieving education for all goals. Kathmandu, Nepal: Author.

UNESCO. (n.d.). Effective literacy practice. Community learning centers - Nepal. Retrieved from http://www.unesco.org/uil/litbase/?menu=4\&programme $=80$

UNESCO International Research and Training Centre for Rural Education. (2001). Education for rural transformation: Towards a policy framework. China: Author.

UNESCO/UNDP. (1985). Nepal - Education for rural development in Seti zone: Project findings and recommendations. Paris, France: Author.

Wood, H. B. (1965). Development of education in Nepal. Washington, DC: Office of Education.

World Bank. (1980). World development report, 1980. Washington, DC: Author. 